\title{
INTELLIGENT PREDICTION MODEL BASED ON GENETIC ALGORITHM AND SUPPORT VECTOR MACHINE FOR EVALUATION OF MINING-INDUCED BUILDING DAMAGE
}

\author{
Lang Liu, Xinping Lai, Ki-Il Song, Dezheng Lao
}

Original scientific paper Characteristics of factors influencing mining-induced building damage are diverse, nonlinear, and multi-linear. For a better description of these factors, an intelligent prediction model for building damage induced by underground mining is developed based on the support vector machine (SVM). Based on a comprehensive consideration of geological, mining, and building factors, 10 factors are carefully selected. In particular, the mining-induced damage grade of the brick-concrete building structure is used as the main input variable in the proposed model. The damage grade and largest crack width of the brickconcrete building structure are selected as output variables in the proposed model. A total of 32 typical cases of mining-induced building damage in China are collected and used as training data. The radial basis function (RBF) is used for SVM classification and the application of the largest-crack-width regression model. To improve the model's generalizability and predictive capacity, the genetic algorithm (GA) is adopted to select effective parameters for the SVM model, and then the corresponding identification of six group samples is performed. The classification and regression results show that the proposed prediction model using GA-SVM can predict the mining-induced damage of a brick-concrete building structure, and the evaluation results show good agreement with monitored data. This suggests the practicality of the proposed model in a wide range of engineering problems.

Keywords: damage grade; genetic algorithm (GA); mining-induced building damage; radial basis function; support vector machine (SVM)

\section{Inteligentni model temeljen na genetskom algoritmu i potpornom vectorskom stroju za predviđanje i procjenu štete na zgradama nastale podzemnim iskapanjem}

Izvorni znanstveni članak Značajke čimbenika koji utječu na štetu nastalu na zgradama zbog iskapanja zemlje su različite, nelinearne i multi linearne. Za bolji opis tih čimbenika razvijen je inteligentni model zasnovan na potpornom vektorskom stroju (SVM) kojim se može predvidjeti šteta na zgradama nastala podzemnim iskapanjem. Na temelju opsežnog razmatranja geoloških, rudarskih i građevnih faktora, 10 ih je pažljivo odabrano. Posebice je, kao glavna ulazna varijabla u predloženom modelu, upotrebljen stupanj oštećenja građevine od opeke i betona, nastao podzemnim iskapanjem. Stupanj oštećenja i najšira pukotina građevinske konstrukcije od opeke i betona izabrani su kao izlazne varijable u predloženom modelu. Ukupno su odabrana 32 tipična slučaja oštećenja zgrada u Kini zbog iskapanja zemlje te upotrebljena kao podaci za uvježbavanje (training data). Funkcija radijalne baze (radial basis function $\mathrm{RBF}$ ) upotrebljena je za SVM klasifikaciju i primjenu modela regresije s najvećom širinom pukotine. Kako bi primjena modela bila što šira i njegova sposobnost predviđanja što veća, za izbor učinkovitih parametara za SVM model upotrebljen je genetski algoritam (GA), i tada je izvršena odgovarajuća identifikacija šest grupa uzoraka. Rezultati klasifikacije i regresije pokazuju da se predloženim modelom, koji koristi GA-SVM, može predvidjeti šteta na konstrukciji od opeke i betona, nastala iskapanjem zemlje, a rezultati procjene u skladu su s praćenim podacima. To navodi na praktičnost primjene predloženog modela u rješavanju različitih inžinjerskih problema.

Ključne riječi: funkcija radijalne baze; genetski algoritam (GA); potporni vektorski stroj (SVM); stupanj oštećenja; šteta na zgradi zbog podzemnog iskapanja

\section{Introduction}

Underground excavation and mining can disturb the equilibrium of the ground and cause surface settlement, which can affect the structural stability of old buildings [1 $\div 4]$. Because of economic growth and urban development, both the intensity and value of buildings in urban areas have increased sharply. As a result, the conflict between the need for underground excavation and the risk of old buildings has received increasing attention, and therefore the number of requirements and its level for qualifying building damage have increased [5 $\div 11]$. Accordingly, recent studies have emphasized risk assessment and defensive measures for buildings near underground excavation sites.

Recent years have witnessed many studies focusing on the mechanisms, prediction, and treatment of mininginduced building damage, particularly with respect to the risk assessment of building damage caused by excavation. Bian and Huang [12] adopt the crack width of the building as an indicator to estimate building damage caused by the excavation of a deep foundation pit. Burland [13] examines potential types of damage and risk levels for London buildings in the context of tunnel excavation. The maximum tensile strain is calculated to assess the risk level. Finno [14] proposes a layered beam model to calculate the maximum bending strain and shear strain to determine the initiation of cracks and assess the risk level. Moorak [15] proposes a four-phase approach to assess building damage from excavation. In this approach, the risk level of structural damage is determined by calculating the angle of the deformation and horizontal strain.

In addition, a series of regulations has been established. For example, the U.K., Poland, and other countries have specified building damage grades [16, 17], and China's State Bureau of Coal Industry has developed a coal pillar design for buildings, waterways, railways, and main roadways as well as coal mining regulations [18] that assign building damage grades for mining subsidence. However, such laws and regulations lack implementation-level guidance and engineering practice and thus can benefit from further theoretical and methodological development.

Because characteristics of factors in the risk assessment of mining-induced building damage are complex, diverse, and nonlinear, it is difficult to determine accurate and user-friendly criteria. Therefore, modern soft computing techniques such as comprehensive fuzzy evaluation methods [19, 20], neural networks [21], and the extension method have been introduced to predict mining-induced building damage. Lian and Guo [19, 20] 
apply fuzzy mathematics to evaluate the grade of damage to brick-concrete structures from coal mining. Guo and Bian [21] construct a damage degree model for predicting mining-induced building damage and use the fuzzy clustering analysis method based on fuzzy equivalence relationships and adaptive back-propagation (BP) neural networks to conduct the grade classification of building damage from mining. Liu et al. [22] propose an extension mathematical model for identifying and evaluating the grade of building damage by applying extension theories and methods.

These methods and models have certain advantages but also have some limitations. Burland's method takes the strain or angle deformation as the main damage indicator. However, such indicators are not intuitive and do not have a distinct physical meaning in terms of structural stability. The comprehensive fuzzy evaluation method entails unavoidable subjectivity and randomness in determining the degree of membership and in assigning weights. The BP neural network method is slow to converge, easily trapped into local optima, and somewhat subjective because of the determination of the hidden layer. With an extension transformation, it is often difficult to determine an appropriate correlation function. Accordingly, because of the difficulty in accurately assessing the level of damage to buildings near underground excavation sites, the aforementioned methods are not sound engineering practices, and therefore there is a need for more scientific and effective evaluation methods.

The support vector machine (SVM) can efficiently perform nonlinear dynamic processing without having to know the relationship between the data distribution and variables, and the method can provide a highly nonlinear mapping $[23,24]$. For practical problems associated with small samples, the nonlinear SVM has important advantages. For example, the SVM is easy to train, does not have a problem with local minima, and can generalize nonlinear processes. However, clear-cut reference criteria have yet to be determined for the selection of SVM parameters and core parameters. The genetic algorithm (GA) is based on laws of biological evolution and shows a high level of adaptive and optimized search ability. In this regard, this study takes advantage of both the SVM and the GA to propose an intelligent prediction model for the accurate and reasonable assessment of building damage caused by underground mining.

\section{Details of SVM theory}

\subsection{The basic SVM classification mode}

Given the training set $\left(x_{i}, y_{i}\right), \mathrm{i}=1,2, \ldots, m, x \in \Omega^{d}$ and $y \in\{-1,+1\}$ can be separated by the hyperplane $w^{\mathrm{T}} x+b$ $=0$, where $w$ is the weight vector and $b$ is the bias. If this hyperplane maximizes the margin, then the following inequality is valid for all input data:

$$
\left(w^{\mathrm{T}} x_{i}+b\right) \cdot y_{i} \geq 1, \text { for all } x_{i}, i=1,2, \cdots m
$$

The margin of the hyperplane is equal to $2 /\|w\|$, and any training tuples that fall on hyperplanes $H_{1}$ or $H_{2}$ (i.e., the sides defining the margin) are support vectors, as shown in Fig. 1. Therefore, this method maximizes the margin by minimizing $\|w\| / 2$ subject to (1). This is a convex quadratic programming $(\mathrm{QP})$ problem.

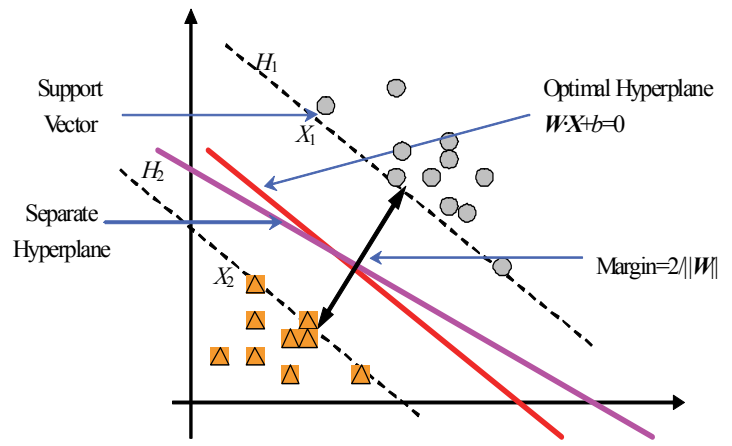

Figure 1 Classification of data by SVM

Lagrange multipliers $\left(\alpha_{i}>0, i=1,2, \ldots, m\right)$ are used to solve the problem

$Q_{p}=-\sum_{i=0}^{m} a_{i}\left[\left(w^{\mathrm{T}} x_{i}+b\right) \cdot y_{i}-1\right]+\|w\|^{2} / 2$,

where $a_{i}^{*}$ are optimal Lagrange multipliers.

After $Q_{p}$ is minimized with respect to both $w$ and $b$, optimal weights are given by $w^{*}=\sum_{i=1}^{m} a_{i}^{*} y_{i} x_{i}$. The dual problem can be described as follows:

$Q_{d}=\sum_{i=1}^{m} a_{i}-\frac{1}{2} \sum_{i=1}^{m} \sum_{j=1}^{m} a_{i} a_{j} y_{i} y_{j} x_{i} x_{j}$.

Lagrange multipliers are only nonzero if $\left(w^{\mathrm{T}} x_{i}+b\right) \cdot y_{i}=1$. The optimal bias for any support vector $x_{i}$ is given by $b^{*}=y_{i}-w^{* \mathrm{~T}} x_{i}$. Therefore, the linear decision function is obtained by solving the dual optimization function (DOF)

$f(x)=\operatorname{sgn}\left(\sum_{i=1}^{m} a_{i}^{*} y_{i} y_{j} x_{i} x^{\mathrm{T}}+b^{*}\right)$,

where $a_{i}^{*}$ are optimal Lagrange multipliers.

For input data with a high level of noise, the SVM uses soft margins that can be expressed as follows through the introduction of nonnegative slack variables $\xi_{i}$, $i=1,2, \ldots, m$ :

$\left(w^{\mathrm{T}} x_{i}+b\right) \cdot y_{i} \geq 1-\xi_{i}$ for $i=1,2, \ldots, m$.

To obtain the optimum separation hyperplane (OSH), $\varphi=C \sum_{i=1}^{m} \xi_{i}^{k}+\frac{1}{2}\|w\|^{2}$ is minimized subject to Eq. (5), where $C$ is the penalty parameter that controls the tradeoff between the complexity of the decision function and the number of misclassified training examples. In nonlinearly separable cases, the SVM maps training 
points nonlinearly to a high-dimensional feature space by using a kernel function $K\left(x_{i}, y_{i}\right)$ in which linear separation is possible. The Gaussian radial basis function $(\mathrm{RBF})$ is one such kernel function and is given by $K(x, y)=\exp \left(-\|x-y\|^{2} / 2 g^{2}\right)$, where $g$ is the width of the RBF kernel. After a kernel function is selected, the QP problem becomes

$Q_{d}(a)=\sum_{i=1}^{m} a_{i}-\frac{1}{2} \sum_{i=1}^{m} \sum_{j=1}^{m} a_{i} a_{j} y_{i} y_{j} K\left(x_{i}, y_{j}\right)$,

where $a_{i}^{*}$ is derived by $a_{i}^{*}=\arg \max _{a} Q_{d}, 0 \leq a_{i} \leq C$, $a=1,2, \cdots, m, i=1,2, \cdots, m, \sum_{i=1}^{m} a_{i} y_{i}=0$.

Accordingly, the decision function is modified as follows:

$$
f(x)=\operatorname{sgn}\left[\sum_{i=1}^{m} a_{i}^{*} y_{i} K\left(x_{i}, x\right)+b^{*}\right] .
$$

\subsection{The SVM regression model}

The basic concept of the support vector regression method is to nonlinearly map original data $x$ into a higher dimensional feature space and solve a linear regression problem in that feature space. First, a linear function is used to regress the data set $V=\left\{\left(x_{i}, x_{j}\right)\right\}_{i}^{p}$, where $x_{i}$ is the input vector for the SVR model; $y_{i}$ is the actual output value from which the SVM learns the input-output relationship; and $p$ denotes the total number of data patterns. The SVM regression model can be expressed as follows:

$$
f(x)=b+w \cdot \varphi(x)
$$

where the function $\varphi(x)$ denotes a high-dimensional kernel-induced feature space and the parameters $w$ and $b$ are support vector weight vectors. A bias term is calculated by minimizing the following regularized risk function:

$$
R(C) \frac{C}{p} \sum_{i=1}^{p} \rho_{\varepsilon}\left(y_{i}, f\left(x_{i}\right)\right)+\|w\|^{2} / 2,
$$

where $C$ denotes a cost function that measures the empirical risk; $\|w\|^{2} / 2$ denotes the regularization term; and $\rho_{\varepsilon}\left(y_{i}, f\left(x_{i}\right)\right)$ is called the $\varepsilon$-insensitive loss function defined as follows:

$\rho_{\varepsilon}\left(y_{i}, f\left(x_{i}\right)\right)=\left\{\begin{array}{l}\left|y_{i}-f\left(x_{i}\right)\right|-\varepsilon\left|y_{i}-f\left(x_{i}\right)\right| \geq \varepsilon \\ 0 \quad \text { otherwise }\end{array}\right.$.
In Eq. (10), the loss is equal to zero if the error of the forecasting value is less than $\varepsilon$ and the forecasting value beyond $\varepsilon$ otherwise.

Two positive slack variables $\xi_{i}$ and $\xi_{i}^{*}, i=1,2, \ldots, n$, can be used to measure the deviation $\left(q_{i}-f\left(x_{i}\right)\right)$ from boundaries of the $\varepsilon$-insensitive zone. That is, they represent the distance from the actual value to the corresponding boundary value for the $\varepsilon$-insensitive zone. With slack variables, Eq. (9) is transformed into the following constrained form:

Minimized,

$\tau\left(w, \xi_{i}+\xi_{i}^{*}\right)=C \sum_{i=1}^{p}\left(\xi_{i}+\xi_{i}^{*}\right)+\|w\|^{2} / 2$

subject to the constraints

$$
\left\{\begin{array}{l}
-b+y_{i}-[w \cdot \varphi(x)] \leq \xi_{i}+\varepsilon \\
-y_{i}+b+[w \cdot \varphi(x)] \leq \xi_{i}^{*}+\varepsilon \\
\xi_{i} \geq 0, \xi_{i}^{*} \geq 0, \text { for } i=1,2, \cdots, p
\end{array} .\right.
$$

The following dual Lagrangian form is found by applying Lagrangian multipliers and Karush-KuhnTucker (KKT) conditions to Eq. (11):

Maximied,

$$
\begin{aligned}
& H\left(a, a^{*}\right)=-\frac{1}{2} \sum_{i, j=1}^{p}\left(a_{i}-a_{i}^{*}\right)\left(a_{j}-a_{j}^{*}\right) K\left(x_{i}, y_{i}\right)+ \\
& +\sum_{i=1}^{p} y_{i}\left(a_{i}-a_{i}^{*}\right)-\varepsilon \sum_{i}^{p}\left(a_{i}+a_{i}^{*}\right),
\end{aligned}
$$

subject to the constraints

$$
\sum_{i=1}^{p}\left(a_{i}-a_{i}^{*}\right)=0, a_{i}, a_{i}^{*} \in[1, C], i \in[1, p]
$$

The Lagrangian multipliers in Eq. (13) satisfy the equality $\alpha_{i} \alpha_{i}{ }^{*}=0$. The Lagrangian multipliers $\alpha_{i}$ and $\alpha_{i}{ }^{*}$ are calculated, and an optimal weight vector of the regression hyperplane is obtained by $w^{*}=\sum_{i=1}^{p}\left(a_{i}-a_{i}^{*}\right) K\left(x_{i}, x\right)$. Therefore, the general form of the SVR-based regression function can be written as follows:

$$
f(x)=b+\sum_{i=1}^{p}\left(a_{i}-a_{i}^{*}\right) K\left(x_{i}, x\right)
$$

Based on KKT conditions for solving the quadratic programming problem $\left(\alpha_{i}-\alpha_{i}^{*}\right)$ in Eq. (14), only some of these values are nonzero. According to Eq. (14), it is evident that support vectors are used only to determine the decision function because coefficients $\left(\alpha_{i}-\alpha_{i}{ }^{*}\right)$ for other data points are all equal to zero. In Eq. (14), $K\left(x_{i}, x\right)$ is called the kernel function. The concept of the kernel 
function $K\left(x_{i}, x\right)=\Phi\left(x_{i}\right) \cdot \Phi(x)$ has been introduced to reduce the computational demand.

SVM studies have used the typical common kernels described in [25] for nonlinear cases, including polynomials, RBFs, Gaussian functions, multilayer perceptrons, and sigmoids, among others. In this way, a nonlinear model in the original space can be transformed into a linear model in the new space. This study constructs the SVM by the Gaussian RBF kernel given in Eq. (8) and because of its superior forecasting performance:

$K(x, y)=\exp \left(-|x-y|^{2} / 2 g^{2}\right)$

where $g$ denotes the width of the RBF.

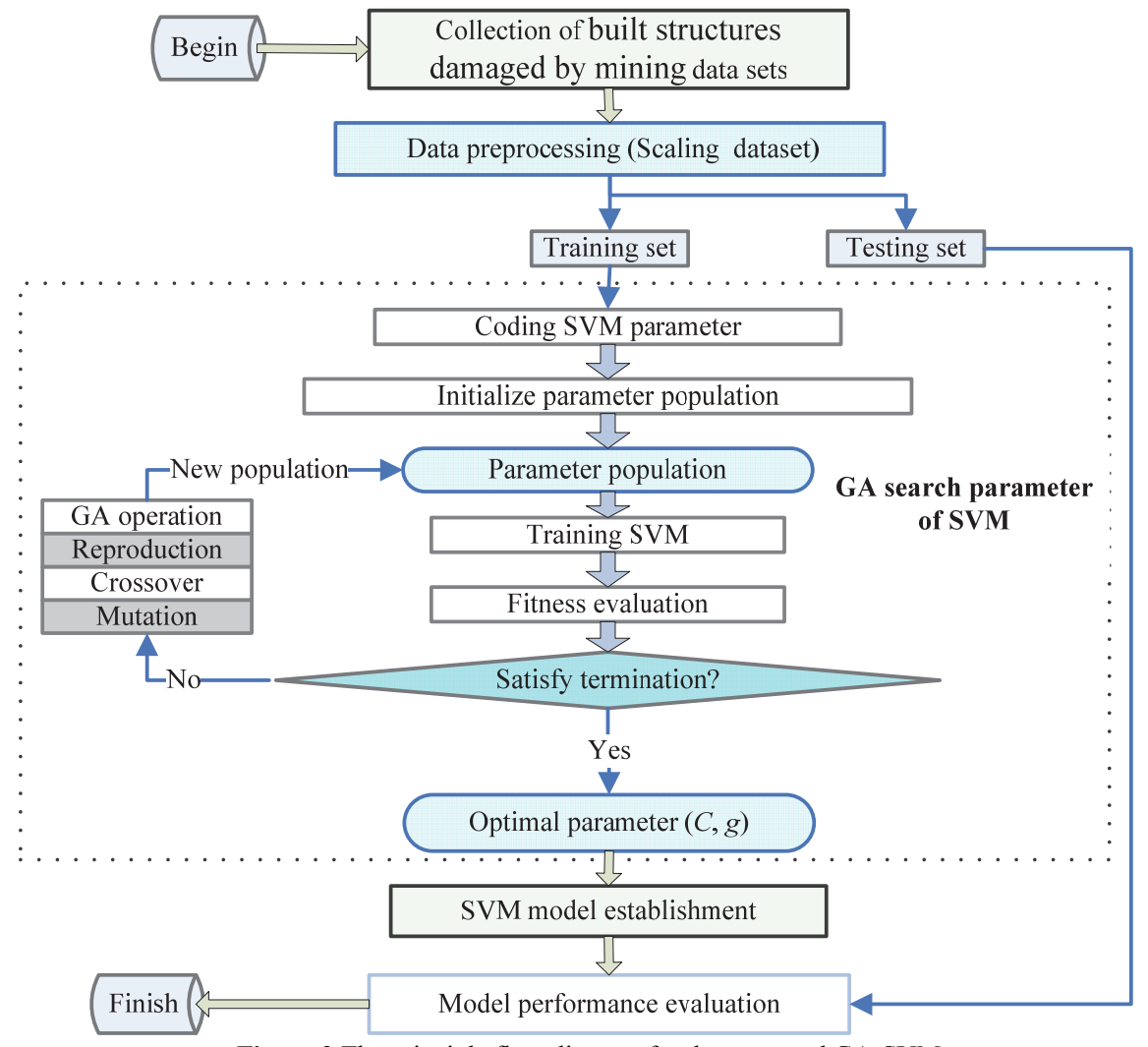

Figure 2 The principle flow diagram for the proposed GA-SVM

\section{Usage process of proposed GA-SVM}

In the SVM algorithm, the selection of $C$ and the parameter $g$ of the kernel function has a substantial impact on exploration predictability and efficiency. The selection of these parameters is typically performed using a manual spreadsheet under experienced guidance, namely by selecting a more satisfactory solution according to the individual. This method is clearly not efficient and subjective and can lead to some difficulty in achieving correct selection and optimal matching for various degrees and complex problems. This limitation greatly hinders the development of the SVM.

The GA has the ability to address complicated problems because it is based on the process of biological evolution, rules governing the survival of the fittest and the chromosome information exchange mechanism. The GA has various advantages and is well described [26 29]. Because of useful features of the GA, the SVM and the GA can be combined to achieve a variety of optimization goals.

For these reasons, this paper proposes a GA-based SVM classification and regression method to search for the best SVM parameters. The specific realization of this process is as follows:
Step 1. Coding: With a binary coding method, express the data error penalty coefficient $C$ for the solution space and the kernel function parameter $g$ as genotype data for the genetic space. Different combinations of genotype data constitute different points.

Step 2. Group initialization: Randomly generate $N$ initial genotype data. Each genotype is referred to as an individual, and $N$ individuals constitute a group. The GA takes $N$ strings as the initial point to start iterations.

Step 3. Individual fitness calculation: Calculate individual fitness and determine whether individuals meet optimization criteria. If met, optimal individuals and their represented solutions are the output, and the calculation is finished. Otherwise, go to step 4.

Step 4. Selection: According to each individual's fitness value, select the top individuals to move to the next group. These individuals have a higher level of adaptable ability and a higher probability of being selected, whereas those individuals of a lower fitness value are likely to be eliminated.

Step 5. Crossover: Individuals in the group are paired, and a portion of the chromosome of an individual is exchanged with its pair according to the condition of the crossover probability. 
Step 6. Variation: For each individual in the group, the probability of variation is used to change certain or some genes to allelic genes.

Step 7. Calculation judgments: Assess whether the group of individuals in the new generation satisfies the end condition. If yes, stop. If not, return to step 3 and continue the calculation.

Step 8. Application: The well-trained GA-SVM model is employed to solve real-world problems.

This calculation flow is shown in Fig. 2.

\section{The prediction of mining-induced building damage with GA-SVM}

\subsection{Input and output parameters of the model}

Building damage is affected by a variety of factors, as described through research and engineering practice [7 $\div 17,19 \div 22$ ], and the ease of access and generalizability of the information analysis must be considered. With a comprehensive consideration of geological, mining, and building factors, the building condition $R$, the location of the cavity $y$, the length $L$, the width $W$, the mining degree comprehensive coefficient $q$, the mining depth $H$, the mining thickness $M$, the Strata average Plats coefficient $f$, the dip angle $\alpha$, and the roof management method $T$ are 10 factors taken as input parameters in the model. For these factors, the building condition $(R)$ is a comprehensive indicator considering the age of the building, properties of its foundation, building materials, the building structure, and building quality. Its classification is described in a qualitative language, and the value is quantified according to Tab. 1 [21]. The relationship between the location of the building and the cavity can be determined by the extent of mining-induced damage and the building's location within the basin. Building situations can be divided into five types, as shown in Tab. 2 [21].

Table 1 The valuation of buildings' situation

\begin{tabular}{|c|c|c|c|c|c|}
\hline Grade & Good & Good & Modest & $\begin{array}{c}\text { Comparatively } \\
\text { bad }\end{array}$ & Bad \\
\hline Valuation & 1,0 & 0,8 & 0,6 & 0,4 & 0,2 \\
\hline
\end{tabular}

Table 2 Position of buildings in the moving basin

\begin{tabular}{|c|c|c|}
\hline Grade & Valuation & $\begin{array}{c}\text { Position of buildings in the moving } \\
\text { basin }\end{array}$ \\
\hline Beneficial & 1 & $\begin{array}{c}\text { In the centre of the moving basin, and } \\
\text { the long axis is perpendicular to the } \\
\text { coal seam alignment }\end{array}$ \\
\hline $\begin{array}{c}\text { Comparatively } \\
\text { beneficial }\end{array}$ & 2 & $\begin{array}{c}\text { Within the borderline of the moving } \\
\text { basin, and the long axis is parallel to the } \\
\text { coal seam alignment }\end{array}$ \\
\hline modest & 3 & $\begin{array}{c}\text { Near the centre of the moving basin, } \\
\text { and the long axis parallels the coal } \\
\text { seam alignment }\end{array}$ \\
\hline $\begin{array}{c}\text { Comparatively } \\
\text { baneful }\end{array}$ & 4 & $\begin{array}{c}\text { Within the border of the moving basin, } \\
\text { and the long axis is perpendicular to the } \\
\text { coal seam alignment }\end{array}$ \\
\hline Baneful & 5 & $\begin{array}{c}\text { In the tension area of the moving basin } \\
\text { and the long axis crosses the coal seam } \\
\text { alignment obliquely. }\end{array}$ \\
\hline
\end{tabular}

To determine building damage based on the BRE building damage classification [30] (Tab. 3); the Rankin evaluation system [31] (Tab. 4); the UK building damage grade specification [32] (Tab. 5); the Portland building damage specification [32] (Tab. 6); building, waterway, railway, and major roadway coal pillar designs; and coal mining regulations [18] (Tab. 7), the building damage grade can be divided into four categories, namely I (ignorable), II (minor), III (medium), and IV (severe), and the maximum crack width of the building can be obtained. The building damage type $\mathrm{D}$ and the maximum crack width $\mathrm{S}$ are taken as model output variables.

Table 3 Classification of building damage by BRE

\begin{tabular}{|c|c|c|}
\hline Damage type & Severity & Crack width $(\mathrm{mm})$ \\
\hline 0 & Ignored & $<0,1$ \\
\hline 1 & Very minor & $0,1 \div 1,0$ \\
\hline 2 & Minor & $1 \div 5$ \\
\hline 3 & Medium & $5 \div 15$ \\
\hline 4 & Severe & $15 \div 25$ \\
\hline 5 & Very severe & $>25$ \\
\hline
\end{tabular}

Table 4 Rankin's evaluation system

\begin{tabular}{|c|c|c|c|c|}
\hline $\begin{array}{c}\text { Maximum } \\
\text { tilt rate }\end{array}$ & $<1 / 500$ & $1 / 500 \div 1 / 200$ & $1 / 200 \div 1 / 50$ & $\geq 1 / 50$ \\
\hline $\begin{array}{c}\text { Maximum } \\
\text { settlement }\end{array}$ & $<10$ & $10 \div 15$ & $50 \div 75$ & $\geq 75$ \\
\hline Severity & Negligible & Slight & Modest & Serious \\
\hline Value & 1 & 2 & 3 & 4 \\
\hline
\end{tabular}

Table 5 The evaluation code for buildings damage in England

Length of buildings $L / \mathrm{m}$ Damage Grade

\begin{tabular}{|c|c|}
\hline Length of buildings $L / \mathrm{m}$ & Damage Grade \\
\hline$<0,03$ & Very minor or ignored \\
\hline $0,03 \div 0,06$ & Minor \\
\hline $0,06 \div 0,12$ & Obvious \\
\hline $0,12 \div 0,18$ & Severe \\
\hline$>0,18$ & Very severe \\
\hline
\end{tabular}

Table 6 The evaluation code for buildings damage in Poland

\begin{tabular}{|c|c|c|c|}
\hline Grade & $\begin{array}{c}\text { Permitted surface } \\
\text { incline value } \\
i(\mathrm{~mm} / \mathrm{m})\end{array}$ & $\begin{array}{c}\text { Permitted surface } \\
\text { deformation value } \\
E(\mathrm{~mm} / \mathrm{m})\end{array}$ & $\begin{array}{c}\text { Permitted surface } \\
\text { radius of curvature } \\
R(\mathrm{~km})\end{array}$ \\
\hline I & 2,5 & 1,5 & $\geq 20$ \\
\hline II & 5,0 & 3,0 & $\geq 12$ \\
\hline III & 10,0 & 6,0 & $\geq 6$ \\
\hline IV & 15,0 & 9,0 & $<1$ \\
\hline V & $>15,0$ & $>9,0$ & $<1$ \\
\hline
\end{tabular}

Table 7 Level specification of the destruction of masonry buildings

\begin{tabular}{|c|c|c|c|c|}
\hline \multirow[b]{2}{*}{$\begin{array}{c}\text { Damage } \\
\text { grade }\end{array}$} & \multicolumn{3}{|c|}{ Surface deformation value } & \multirow[b]{2}{*}{ Measurements } \\
\hline & $\begin{array}{c}\text { Title value } \\
i(\mathrm{~mm} / \mathrm{m})\end{array}$ & $\begin{array}{l}\text { Radius of } \\
\text { curvature } \\
K\left(10^{-3} / \mathrm{m}\right) \\
\end{array}$ & $\begin{array}{c}\text { Vertical } \\
\text { deformation } \\
E(\mathrm{~mm} / \mathrm{m}) \\
\end{array}$ & \\
\hline $\mathrm{I}$ & $\leq 3,0$ & $\leq 0,2$ & $\leq 2,0$ & No maintenance \\
\hline II & $\leq 6,0$ & $\leq 0,4$ & $\leq 4,0$ & $\begin{array}{c}\text { Minor } \\
\text { maintenance }\end{array}$ \\
\hline III & $\leq 10,0$ & $\leq 0,6$ & $\leq 6,0$ & $\begin{array}{l}\text { Intermediate } \\
\text { repair }\end{array}$ \\
\hline IV & $>10,0$ & $>0,6$ & $>6,0$ & $\begin{array}{c}\text { Major } \\
\text { maintenance, } \\
\text { Reconstruction } \\
\text { or demolition }\end{array}$ \\
\hline
\end{tabular}

\subsection{Data normalization}

To verify the effectiveness and practicality of the proposed SVM model, 32 cases of building damage induced by underground mining in $[20,21]$ are used as learning and training samples (Tab. 8) and test samples (Tab. 9). The data set is visualized in Fig. 3. To transform data, which have different dimensions and value ranges, into a single-value range (the same scale), sample data are normalized. Accordingly, input variables for the SVM prediction model are processed using the following standardized pretreatment procedure. 
Table 8 Typical cases for training data

\begin{tabular}{|c|c|c|c|c|c|c|c|c|c|c|c|c|c|c|c|}
\hline \multirow[b]{2}{*}{ NO. } & \multirow[b]{2}{*}{ Names of buildings } & \multicolumn{4}{|c|}{ Building conditions } & \multicolumn{6}{|c|}{ Factors of geological mining } & \multicolumn{2}{|c|}{$\begin{array}{l}\text { Damage } \\
\text { grade } D\end{array}$} & \multicolumn{2}{|c|}{$\begin{array}{l}\text { Maximum } \\
\text { crack width } \\
S(\mathrm{~mm}) \\
\end{array}$} \\
\hline & & 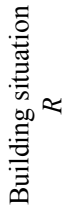 & 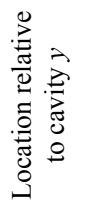 & 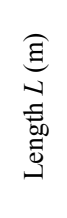 & 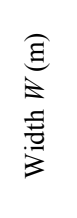 & 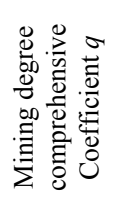 & 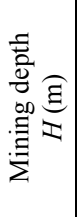 & 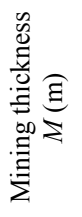 & 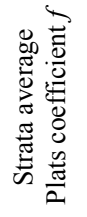 & 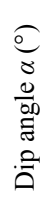 & 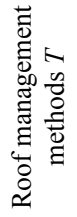 & $\begin{array}{l}\frac{\pi}{0} \\
\frac{\tilde{J}}{0} \\
\frac{0}{0} \\
.1\end{array}$ & $\sum_{\infty}^{\infty}$ & $\begin{array}{l}\frac{\pi}{0} \\
\frac{\pi}{0} \\
\frac{0}{0} \\
\frac{0}{1}\end{array}$ & $\sum_{\infty}^{\infty}$ \\
\hline 1 & $\begin{array}{l}\text { Room } 11 \text { of Feng-Feng } \\
\text { NO. } 5 \text { mine }\end{array}$ & 1,0 & 2 & 26 & 6,0 & 0,9225 & 188 & 2,2 & 4,8 & 22 & 0 & II & II & 10 & 13,21 \\
\hline 2 & $\begin{array}{l}\text { Room } 13 \text { of Feng-Feng } \\
\text { NO. } 5 \text { mine }\end{array}$ & 0,6 & 5 & 36 & 13,0 & 0,9225 & 188 & 2,2 & 4,8 & 22 & 0 & IV & IV & 60 & 56,80 \\
\hline 3 & $\begin{array}{l}\text { Room } 1 \text { of } \mathrm{He}-\mathrm{Bi} \text { NO. } 1 \\
\text { mine }\end{array}$ & 0,6 & 5 & 27,8 & 6,7 & 0,8165 & 270 & 7,5 & 3 & 25 & 0 & IV & IV & 56 & 59,20 \\
\hline 4 & $\begin{array}{l}\text { Hospital admission } \\
\text { office of Benxicaitun }\end{array}$ & 0,6 & 5 & 20 & 12,0 & 0,3346 & 541 & 4,3 & 5 & $\begin{array}{c}13 \\
5\end{array}$ & 0 & III & III & 28 & 27,83 \\
\hline 5 & $\begin{array}{l}\text { Out-patient clinics of } \\
\text { Benxicaitun }\end{array}$ & 0,8 & 5 & 27,5 & 11,0 & 0,3317 & 565 & 3,25 & 5 & 14 & 0 & III & III & 22 & 25,19 \\
\hline 6 & $\begin{array}{l}\text { Culture castle of } \\
\text { Benxicaitun }\end{array}$ & 0,6 & 5 & 27,8 & 20,0 & 0,3321 & 559 & 3,5 & 5 & 14 & 0 & III & III & 25 & 21,80 \\
\hline 7 & $\begin{array}{l}\text { Room } 5 \text { of Zao-zhuang } \\
\text { elementary school }\end{array}$ & 0,4 & 4 & 24 & 6,7 & 0,8756 & 120 & 2 & 3,2 & 6 & 0 & IV & IV & 44 & 47,20 \\
\hline 8 & Car platform of Gan-lin & 0,6 & 3 & 10 & 8,0 & 0,8032 & 217 & 1,01 & 3,7 & 15 & 0 & $\mathrm{I}$ & $\mathrm{I}$ & 1 & 4,19 \\
\hline 9 & $\begin{array}{l}57 \text { workshop of Gan-lin } \\
\text { mine }\end{array}$ & 0,6 & 3 & 28 & 12,0 & 0,8944 & 196 & 1,0 & 3,7 & 16 & 0 & I & I & 2 & 5,44 \\
\hline 10 & A club in Gan-lin & 0,6 & 4 & 26,4 & 22,5 & 0,7016 & 260 & 1,01 & 3,7 & 12 & 0 & I & $\mathrm{I}$ & 1 & 4,19 \\
\hline 11 & $\begin{array}{l}\text { Warehouse of Feng- } \\
\text { Feng NO. } 5 \text { mine }\end{array}$ & 0,8 & 4 & 12,6 & 8,5 & 0,9225 & 188 & 2,2 & 4,8 & 22 & 0 & IV & IV & 44 & 40,79 \\
\hline 12 & $\begin{array}{l}\text { Dweller house } 1 \text { of } \\
\text { Yungaishan }\end{array}$ & 1,0 & 2 & 15,1 & 5,5 & 0,5916 & 163 & 4,8 & 4,2 & 17 & 0 & III & III & 20 & 16,79 \\
\hline 13 & $\begin{array}{l}\text { Dweller house } 2 \text { of } \\
\text { Yungaishan }\end{array}$ & 0,8 & 2 & 10,8 & 5,5 & 0,5916 & 163 & 4,8 & 4,2 & 17 & 0 & II & II & 14 & 19,06 \\
\hline 14 & $\begin{array}{l}\text { Dweller house } 1 \text { of } \\
\text { Jiaozuofengying mine }\end{array}$ & 0,6 & 2 & 14,1 & 5,8 & 0,9045 & 132 & 2,1 & 5,2 & 19 & 0 & III & III & 22 & 18,80 \\
\hline 15 & $\begin{array}{l}\text { Dweller house } 2 \text { of } \\
\text { Jiaozuofengying mine }\end{array}$ & 1,0 & 1 & 14,1 & 5,8 & 0,9045 & 132 & 2,1 & 5,2 & 19 & 0 & I & I & 3 & 6,20 \\
\hline 16 & $\begin{array}{l}\text { Room } 50 \text { of He-bi NO. } \\
6 \text { mine }\end{array}$ & 0,6 & 4 & 17,8 & 5,2 & 0,8165 & 170 & 7,5 & 3 & 25 & 0 & IV & IV & 65 & 57,76 \\
\hline 17 & $\begin{array}{l}\text { Shun-li mine } \\
\text { (Paediatrics) }\end{array}$ & 0,2 & 4 & 56 & 10,0 & 0,4899 & 514 & 40 & 2 & 27 & 1 & IV & IV & 30 & 26,81 \\
\hline 18 & $\begin{array}{l}\text { Dongguag village Tiger } \\
\text { platform mine }\end{array}$ & 1,0 & 3 & 10,5 & 5,5 & 0,4094 & 454 & 26 & 2 & 47 & 1 & II & II & 8 & 11,21 \\
\hline 19 & $\begin{array}{l}\text { A shelter of Guan St, } \\
\text { Shun-li mine }\end{array}$ & 1,0 & 2 & 15,5 & 3,9 & 0,2116 & 576 & 38 & 2 & 25 & 1 & I & I & 2 & 5,21 \\
\hline 20 & $\begin{array}{l}\text { Office building of } \\
\text { Huanzhuang NO. } 2 \\
\text { mine }\end{array}$ & 1,0 & 1 & 35,0 & 14,7 & 0,4119 & 132 & 4,8 & 4,6 & 8 & 0 & II & II & 12 & 15,21 \\
\hline 21 & An office of shunli & 0,6 & 2 & 36,1 & 12,0 & 0,3238 & 543 & 20 & 2 & 24 & 1 & II & II & 9 & 9,51 \\
\hline 22 & $\begin{array}{l}\text { Maintenance room of } \\
\text { Shun-li mine }\end{array}$ & 0,6 & 1 & 35,0 & 12,0 & 0,3238 & 534 & 20 & 2 & 24 & 1 & II & II & 5 & 8,22 \\
\hline 23 & $\begin{array}{l}\text { Building of } 7 \text { miles NO. } \\
1 \text { mine }\end{array}$ & 0,6 & 2 & 27,0 & 4,50 & 0,3411 & 110 & 2,1 & 4,2 & 11 & 0 & III & III & 20 & 16,79 \\
\hline 24 & Room 51 of He-bi & 0,8 & 5 & 21,5 & 6,20 & 0,8165 & 270 & 7,5 & 3 & 25 & 0 & IV & IV & 48 & 51,19 \\
\hline 25 & $\begin{array}{l}\text { Flat dormitory of Gan- } \\
\text { lin mine }\end{array}$ & 1,0 & 4 & 22,0 & 6,20 & 0,8032 & 217 & 1,01 & 3,7 & 15 & 0 & I & I & 1 & 4,20 \\
\hline 26 & $\begin{array}{l}\text { Iron workshop of Feng- } \\
\text { Feng NO. } 5 \text { mine }\end{array}$ & 0,8 & 3 & 37,0 & 10,0 & 0,9225 & 188 & 2,2 & 4,8 & 22 & 0 & IV & IV & 40 & 28,14 \\
\hline 27 & $\begin{array}{l}\text { Wood warehouse of He- } \\
\text { Bi NO. } 2 \text { mine }\end{array}$ & 0,2 & 5 & 29,2 & 8,49 & 0,8311 & 325 & 1,92 & 3,2 & 17 & 0 & IV & IV & 39 & 35,81 \\
\hline 28 & $\begin{array}{l}\text { An office of He-Bi NO. } \\
2 \text { mine }\end{array}$ & 1,0 & 1 & 14,1 & 6,0 & 0,8331 & 325 & 1,92 & 3,2 & 17 & 0 & I & I & 4 & 0,80 \\
\hline 29 & $\begin{array}{l}\text { Dweller house NO. } 1 \text { of } \\
\text { Jiaozuo } 9 \text { miles }\end{array}$ & 0,4 & 3 & 12,1 & 4,2 & 0,7113 & 168 & 2,8 & 5,1 & 15 & 0 & III & III & 23 & 26,20 \\
\hline 30 & $\begin{array}{l}\text { Dweller house NO. } 2 \text { of } \\
\text { Jiaozuo } 9 \text { miles }\end{array}$ & 0,6 & 2 & 10,5 & 3,8 & 0,7113 & 168 & 2,8 & 5,1 & 15 & 0 & II & II & 15 & 11,80 \\
\hline 31 & $\begin{array}{l}\text { Dweller house NO. } 1 \text { of } \\
\text { Yongcheng Gedian } \\
\text { mine }\end{array}$ & 0,6 & 3 & 14,0 & 4,5 & 0,4962 & 390 & 2,9 & 2,6 & 6 & 0 & II & II & 10 & 10,07 \\
\hline 32 & $\begin{array}{l}\text { Dweller house NO. } 2 \text { of } \\
\text { Yongcheng Gedian } \\
\text { mine }\end{array}$ & 1,0 & 1 & 12,5 & 3,8 & 0,4962 & 390 & 2,9 & 2,6 & 6 & 0 & I & I & 1 & 4,20 \\
\hline
\end{tabular}

Note: Building situation: $R$; Location relative to cavity: $y$; Length: $L(\mathrm{~m})$; Width: $W(\mathrm{~m})$; Mining degree comprehensive coefficient: $q$; Mining depth: $H$ $(\mathrm{m})$; Mining thickness: $M(\mathrm{~m})$; Strata average Plats coefficient: $f$; Dip angle: $\alpha\left({ }^{\circ}\right)$; Roof management method: $T$. 


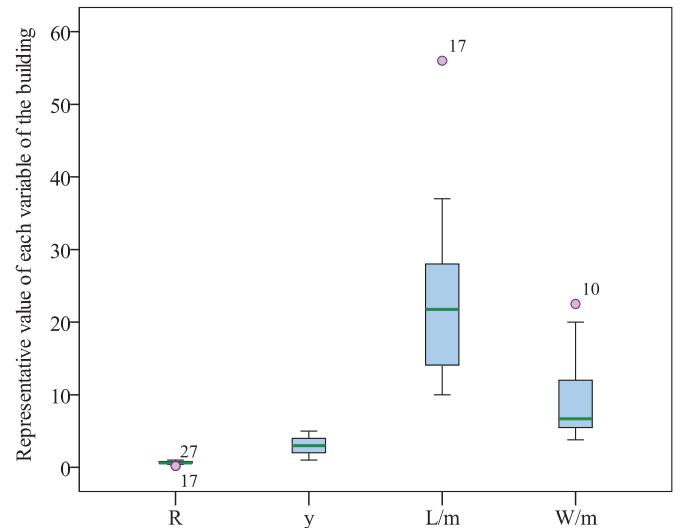

(a)

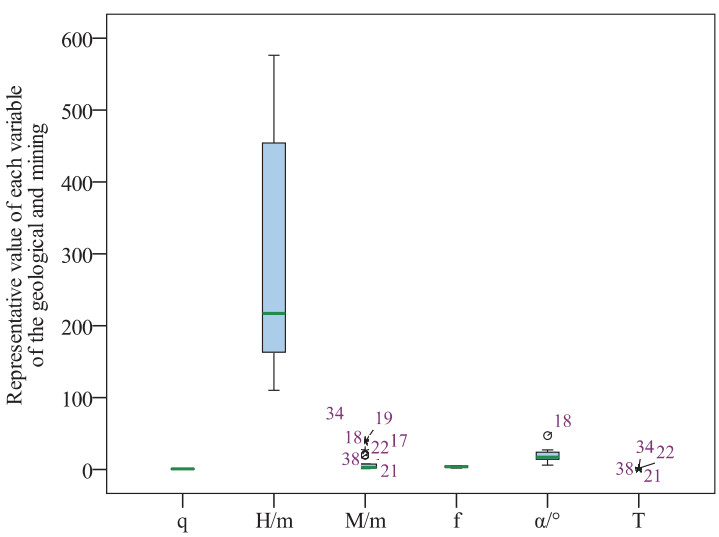

(b)

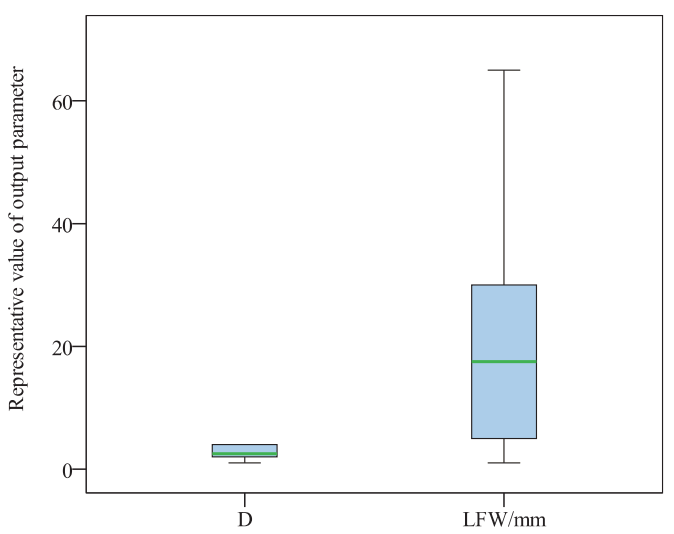

(c)

Figure 3 The visualization of building damage

Suppose the maximum and minimum values of variables are $v_{\max }$ and $v_{\min }$, respectively. Then a standardized variable for a certain sample $v$ can be defined as

$v_{\text {norm }}=\frac{v-v_{\min }}{v_{\max }-v_{\min }}$.

The value range of each output variable is within $[0$, 1], and each output variable has the same dimensionless quantity.

\subsection{Parameter optimization}

Based on previous research $[26 \div 29]$, this paper selects the RBF kernel. With respect to the GA-SVM model, the RBF kernel parameter $g$ and the penalty factor $C$ ( $g$ and $C$ are suitable as sample characteristics) are determined using the GA to eliminate the risk of low prediction accuracy from improper SVM parameter settings. The key to finding the best scale parameter $g$ and the penalty factor $C$ in the SVM by using the GA is in the chromosome coding. First, the number of genes in the chromosome is set to 20 , and $\mathrm{g}$ and $C$ are then set according to experience. Then the parameters are discretized and binary encoded according to the set scope. If $g \in(0,10)$, then the step size is $10 / 1024$; the binary encoding is $0000000001 \div 1111111111$; and a binary number is used as a gene. With the binary string of $g, X=$ $x_{1} x_{2} \ldots x_{10} ; C \in(0,100]$, the step size is $100 / 1024$, and the binary string is 0000000001 to 1111111111 . Then with $Y=y_{1} y_{2} \ldots y_{10}, X Y=x_{1} x_{2} \ldots x_{10} y_{1} y_{2} \ldots y_{10}$. The mapping function can be written as follows:

$g=f_{g} \cdot X, C=f_{C} \cdot Y$.

After the genetic manipulation, chromosomes are decoded to the real scale parameter $g$ and the real penalty factor $C$.

\subsection{Grade evaluation of building damage}

Based on a set of measured data from the literature [20, 21], the SVM model for assessing mining-induced building damage is constructed. The data set is shown in Tables 7 and 8. In evaluating the building's maximum crack width $S$, the SVM model input vector is $(R, y, L, W$, $q, H, M, f, \alpha, T)$; the model output damage grade is $\mathrm{S}$; and the mapping is $S \rightarrow F(R, y, L, W, q, H, M, f, \alpha, T)$. For classification problems, there are two main parameters affecting SVM classification results: the error penalty parameter $C$ and the kernel function parameter $g$. The error penalty parameter $C$ serves to adjust the ratio of the learning machine confidence range to the empirical risk within the determined data subspace, thereby enabling the generalizability of the learning machine (the optimal $C$ is different within different data subspaces). The parameter $\mathrm{g}$ is affected mainly by the distribution of the degree of complexity of sample data in a high-dimensional eigenspace. With the help of Libsvm Support Vector Machine Toolbox [33], Matlab is used to program GASVM model parameters. The training sample crossvalidation method for determining $\mathrm{g}$ and $\mathrm{C}$ employs the Matlab genetic algorithm toolbox, and the gradual heuristic optimisation is performed. More specifically, let $C \in[0,102], g \in[0,102]$. The maximum evolution generation is 100; the largest group population is 20 ; the crossover probability is 0,9 ; the variation probability is 0,05 ; and the cross-validation time for the SVM is 5 . Then the relationship between the fitness value and the evolutionary generation can be obtained, as shown in Fig. 4. Finally, the optimal parameter $\mathrm{g}$ is determined as 16,$881 ; C$, as 90,305 ; and training accuracy, as $93,33 \%$. Fig. 4 shows that the best fit value increases with an increase in the generation (this is the effect of GA evolution). After 23 generations of evolution, the optimal fitness value converges. Then optimal parameters are calculated as $(C, g)=(12,6063 ; 0,62256)$. This outcome indicates that the sample results for the GA-SVM model are accurate (Tab. 8) and that the classification model is 
highly stable. With a well-trained GA-SVM model for six samples, the results show good agreement with real data and the BP neural network method [12]. The error rate is
0 (Tab. 9). In addition, this result shows that the GASVM model for identifying and forecasting mininginduced building damage is reliable and effective.

\begin{tabular}{|c|c|c|c|c|c|c|c|c|c|c|c|c|c|c|c|}
\hline \multirow[b]{2}{*}{ NO. } & \multirow[b]{2}{*}{ Names of buildings } & \multicolumn{4}{|c|}{ Building conditions } & \multicolumn{6}{|c|}{ Factors of geological mining } & \multicolumn{2}{|c|}{$\begin{array}{l}\text { Damage } \\
\text { grade } D\end{array}$} & \multicolumn{2}{|c|}{$\begin{array}{c}\text { Maximum } \\
\text { crack } \\
\text { width } \\
S(\mathrm{~mm}) \\
\end{array}$} \\
\hline & & 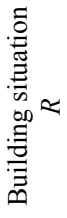 & 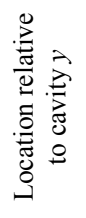 & 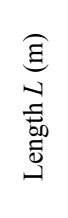 & 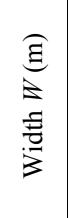 & 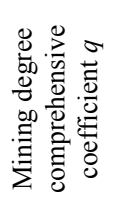 & 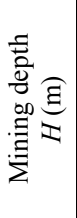 & 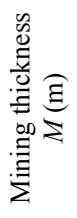 & 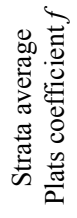 & 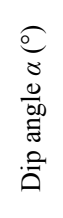 & 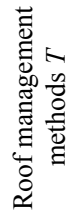 & $\begin{array}{l}\frac{\pi}{\pi} \\
\frac{\pi}{0} \\
\frac{0}{0}\end{array}$ & $\sum_{\infty}^{\infty}$ & 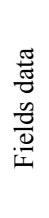 & $\sum_{i s}$ \\
\hline 33 & $\begin{array}{l}\text { Dweller house } 3 \text { of } \\
\text { Jiaozuofengying }\end{array}$ & 0,8 & 2 & 14,1 & 5,8 & 0,9045 & 132 & 2,1 & 5,2 & 19 & 0 & II & II & 10 & 9,27 \\
\hline 34 & $\begin{array}{l}\text { A power substation of } \\
\text { Shunli mine }\end{array}$ & 0,6 & 3 & 20,0 & 12,0 & 0,4899 & 514 & 40 & 2 & 27 & 1 & II & II & 14 & 13,77 \\
\hline 35 & $\begin{array}{l}\text { Dormitory of Hanzhuang } \\
\text { NO, } 2 \text { mine }\end{array}$ & 0,4 & 4 & 36,0 & 12,0 & 0,4119 & 132 & 4,8 & 4,6 & 8 & 0 & IV & IV & 48 & 48,86 \\
\hline 36 & $\begin{array}{l}\text { Guesthouse of Hanzhuang } \\
\text { NO, } 2 \text { mine }\end{array}$ & 0,6 & 2 & 35,0 & 7,0 & 0,4119 & 132 & 4,8 & 4,6 & 8 & 0 & III & III & 28 & 28,14 \\
\hline 37 & $\begin{array}{l}\text { A dweller house } \\
\text { of Xin-shizhuang }\end{array}$ & 0,4 & 1 & 15,0 & 14,0 & 1,0000 & 437 & 1,1 & 4,8 & 14,5 & 0 & I & I & 2 & 1,95 \\
\hline 38 & $\begin{array}{l}\text { Boarding school office of } \\
\text { Shun-li mine }\end{array}$ & 0,4 & 4 & 22,0 & 5,4 & 0,3239 & 530 & 20 & 2 & 24 & 1 & III & III & 27 & 26,89 \\
\hline
\end{tabular}

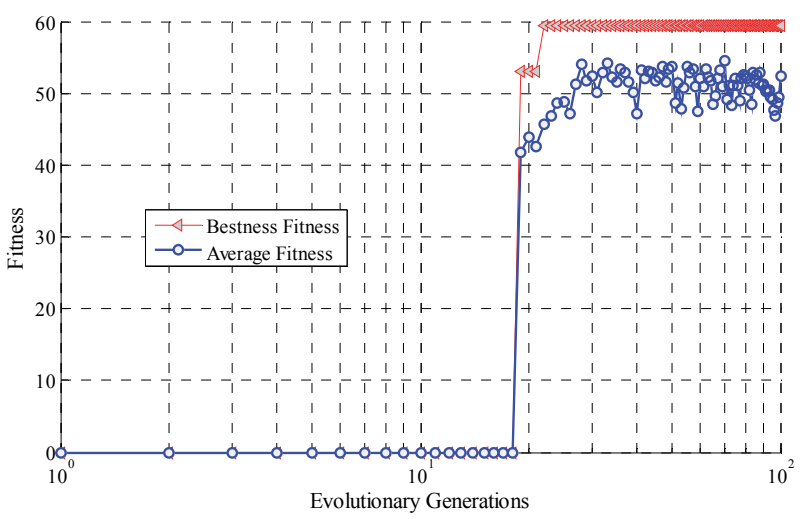

Figure 4 Fitness curves of the damage degree based on the GA

\subsection{Prediction of the maximum building crack width}

In evaluating the grade of building damage, the SVM model input vector is $(R, y, L, W, q, H, M, f, \alpha, T)$, the model output damage level is $D$, and the mapping can be obtained as $D \rightarrow F(R, y, L, W, q, H, M, f, \alpha, T)$. In the SVM regression problem, the penalty factor $C$ determines the fitness of the function. A higher $C$ value leads to the assignment of more support vectors, but if the value of $C$ is too high, it affects SVM regression performance. Therefore, the selection of a suitable penalty factor for the regression analysis is particularly important. The insensitive parameter $g$ indicates the accuracy of the regression curve. The higher the value of $g$, the lower the generalization performance for the regression curve is. With the Gaussian kernel function (RBF) as the kernel function in training the sample, the best combination $(C$, $g$ ) of SVM parameters is optimized by employing the stated GA method. In addition, to obtain the optimal parameter $(C, g)$, the binary coding method is used. GA control parameter settings are as follows: The group size is 20 , the maximum number of generations is 100 , the encoding length of both $C$ and $g$ is 5 , the crossover rate is
0.9 , and the variation rate is 0,05 . The optimization range of each parameter is $0 \leq C \leq 100,0 \leq g \leq 100$. The squared correlation coefficient $\left(R^{2}\right)$ and the mean square error (MSE) are used as a final evaluation indicator:

$$
\begin{aligned}
& R^{2}=1-\frac{\sum_{i}\left(O_{i}-T_{i}\right)^{2}}{\sum_{i}\left(O_{i}\right)^{2}}, \\
& M S E=\sqrt{\frac{\left(O_{i}-T_{i}\right)^{2}}{n}},
\end{aligned}
$$

where $T_{i}, O_{i}$, and $n$ represent the measured output, the predicted output, and the number of input-output data pairs, respectively.

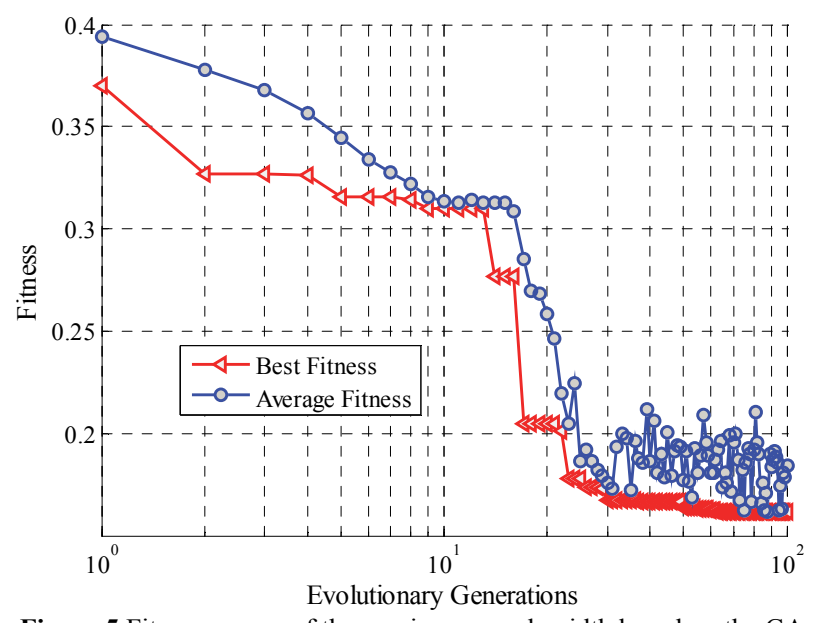

Figure 5 Fitness curves of the maximum crack width based on the GA

The relationship between the evolutionary generation and the GA parameter selection fitness of the maximum 
crack is shown in Fig. 5. If the model's optimal parameters are $C=5,2465, g=0,21496$, then the test sample $M S E$ is $0,001486, R^{2}$ is 0,96053 . As shown in Fig. 6 , the prediction curve of samples trained using the SVM regression method has a good fit.

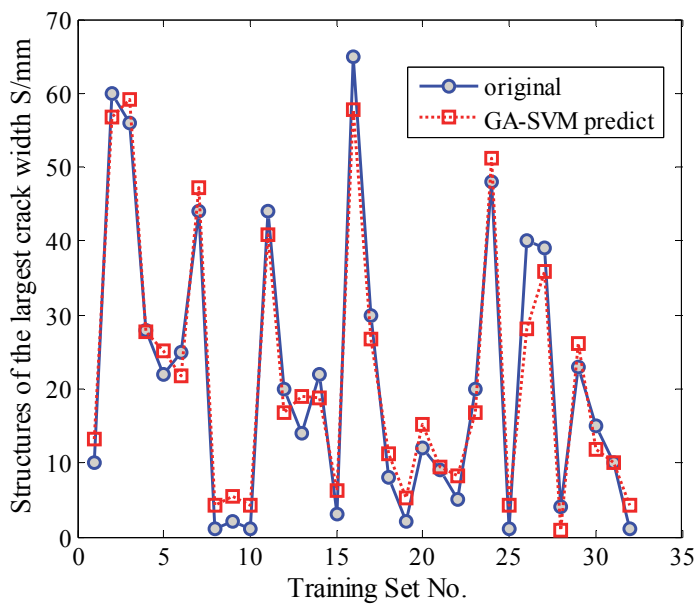

Figure 6 A comparison of the predicted maximum crack width based on the GA-SVM regression model and the original method

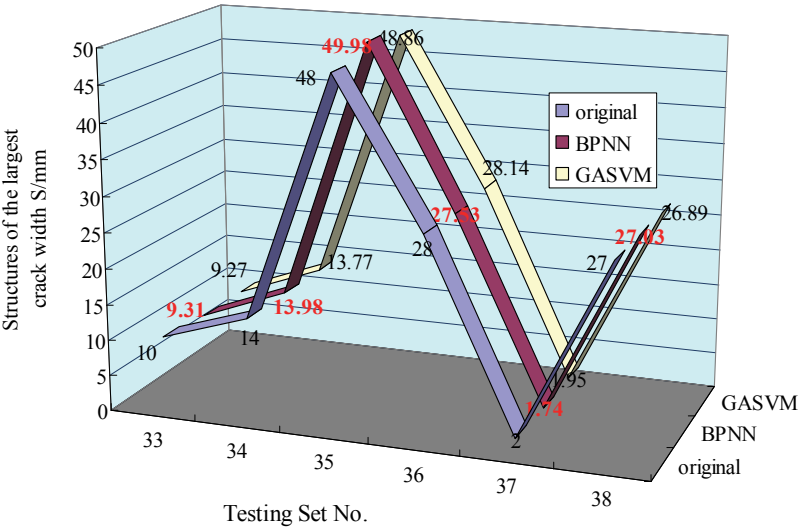

Figure 7 A comparison of the predicted maximum crack width based on the GA-SVM regression model, the back-propagation neural network, and the original method

The results of a prediction error analysis and a comparison of the BP neural network and the GA-SVM are shown in Fig. 6. Previous research [21] shows the largest absolute error of the maximum crack width to be $1,98 \mathrm{~mm}$. The relative error is comparatively larger. The maximum absolute error of the GA-SVM model is only $0,86 \mathrm{~mm}(<<1,98 \mathrm{~mm})$. The predictive accuracy of the GA-SVM model exceeds that of the traditional BP neural network. As shown in Figs. 6 and 7 and Tabs. 8 and 9, the proposed SVM classification and regression model can effectively predict building damage induced by underground mining. That is, the assessment results are consistent with monitored results, and the model accurately classifies the building damage grade. Therefore, the combination of the GA and the SVM can not only ensure the generalizability of the SVM but also provide an SVM with a higher level of learning ability. The application of SVM theory to the assessment of mining-induced building damage is feasible, and this theory can objectively reflect real-world situations. This model can be applied to engineering practice to determine the level of damage, identify the form of compensation, and determine compensation standards, and it can make building compensation work more scientifically and reasonably. The GA based on more groups can obtain several extreme values from different points, and therefore the obtained solution is globally optimal. However, it is difficult to examine the GA separately and effectively as a control method. SVM characteristics are based on the principle of structural risk minimization and have good generalizability. This system represents a convex quadratic optimization problem, and this ensures that the extreme solution is globally optimal and unique. This restriction avoids the risk of falling into local minima and effectively addresses the curse of dimensionality. However, there remain no perfect reference criteria for selecting SVM parameters and core parameters that affect model performance. The GA draws from the laws of biological evolution and can provide good adaptive optimization performance. Therefore, the combination of the GA and the SVM cannot only incorporate the generalizability of the SVM but also improve the learning ability of the SVM.

\section{Conclusion}

An intelligent prediction model for building damage induced by underground mining is developed based on the SVM. The RBF is used to perform SVM classification and apply the largest-crack-width regression model. To improve the generalizability and predictive capacity of the model, the GA is introduced to tune the model's parameters.

From a comprehensive consideration of geological, mining, and building factors, 10 influential factors are carefully selected. In particular, the mining-induced damage grade of the brick-concrete building structure is derived as the main input variable for the proposed prediction model. The damage grade and largest crack width of the brick-concrete building structure are selected as output variables. A number of cases of mining-induced building damage are trained and tested. The classification and regression results show that the proposed GA-SVM model can predict the mining-induced damage of a brickconcrete building structure. The results suggest that the proposed model is practical and can be applied to a wide range of engineering problems.

Future research should consider and evaluate additional characteristics by using the proposed model for a better understanding of the mechanism underlying building damage induced by mining. Because the GASVM model is constructed using the learning law of factor characteristics and survey data from damaged buildings, the number of learning samples and their representativeness are crucial for the accuracy of predicting building damage induced by underground mining.

\section{Acknowledgements}

The authors would like to thank the 973 National Key Basic Research Development Program (2015CB251600), the Key National Natural Science Foundation of China (U13612030), the Key Scientific and Technological Innovation Team Projects of Shaanxi Province 
(2013KCT-16) is gratefully acknowledged. This research was also supported by the Power Generation \& Electricity Delivery of the Korea Institute of Energy Technology Evaluation and Planning (KETEP) grant funded by the Korea government Ministry of Trade, industry \& Energy (No. 20131010501790). This work is supported by INHA university research grant.

\section{References}

[1] Yang, J. S.; Liu, B. C.; Wang, M. C. Modeling of tunneling-induced ground surface movements using stochastic medium theory. // Tunnelling and Underground Space Technology. 19, 2(2004), pp. 113-123. DOl: 10.1016/j.tust.2003.07.002

[2] Li, W. X.; Dai, L. F.; Hou, X. B.; Lei, W. Fuzzy genetic programming method for analysis of ground movements due to underground mining. // International Journal of Rock Mechanics and Mining Science. 44, 6(2007), pp. 954-961. DOI: 10.1016/j.jijmms.2007.02.003

[3] Lee, S.; Park, I.; Choi, J. K. Spatial prediction of ground subsidence susceptibility using an artificial neural network. // Environmental Management. 49, 2(2012), pp. 347-358. DOI: $10.1007 /$ s00267-011-9766-5

[4] Can, E.; Kuscu, S.; Mekik, C. Determination of underground mining induced displacements using GPS observations in Zonguldak-Kozlu hard coal basin. // International Journal of Coal Geology. 89, 1(2012), pp. 6269. DOI: $10.1016 /$ j.coal.2011.08.006

[5] Salajka, V.; Kaláb, Z.; Kala, J.; Hradil, P. Response of the residential building structure on load technical seismicity due to mining activities. // World Academy of Science, Engineering and Technology. 3, (2009), pp. 165-173.

[6] Malinowska, A.; Hejmanowski, R. Building damage risk assessment on mining terrains in Poland with GIS application. // International Journal of Rock Mechanics and Mining Science. 47, 2(2010), pp. 238-245. DOl: 10.1016/j.jijmms.2009.09.009

[7] Malinowska, A. A fuzzy inference-based approach for building damage risk assessment on mining terrains. // Engineering Structures. 33, 1(2011), pp. 163-170. DOl: 10.1016/j.engstruct.2010.10.001

[8] Herrera, G.; Álvarez Fernández, M. I.; Tomás, R.; González-Nicieza, C.; López-Sánchez, J. M.; Álvarez Vigil, A. E. Forensic analysis of buildings affected by mining subsidence based on Differential Interferometry (Part III). // Engineering Failure Analysis. 24, (2012), pp. 67-76. DOI: 10.1016/j.engfailanal.2012.03.003

[9] Selby, A. R. Tunneling in soil-ground movements and damage to buildings in workington, UK. // Geotechnical and Geological Engineering. 17, 3-4(1999), pp. 351-371.

[10] Shi, X. Z.; Zhou, J.; Cui, S.; Huang, M.; Qiu, X. Y.; Sun, L. Distance discriminant analysis model and its application for prediction residential house's damage against blasting vibration of open pit mining. // Journal of Central South University (Science and Technology). 42, 2(2011), pp. 441448.

[11] Najjar, Y.; Zaman, M. Numerical modeling of ground subsidence due to mining. // International Journal of Rock Mechanics and Mining Sciences \& Geomechanics Abstracts. 30, 7(1993), pp. 1445-1448. DOI: 10.1016/01489062(93)90135-Z

[12] Bian, Y. H.; Huang, H. W. Risk assessment of building damage induced by deep excavation. // Chinese Journal of Geotechnical Engineering. 28, Supp.1 (2006), pp. 18921896.
[13] Burland, J. B.; Wroth, C. P. Settlement of buildings and associated damage. // Proceedings of Conference on Settlement of Structures / London, 1974, pp. 611-654.

[14] Finno, R. J.; Voss, F. T; Rossow, E.; Blackburm, J. T. Evaluating damage potential in buildings affected by excavations. // Journal of Geotechnical and Geoenvironmental Engineering. 131, 10(2005), pp. 11991210. DOI: 10.1061/(ASCE)1090-0241(2005)131:10(1199)

[15] Moorak S.; Edward J. C. Estimation of building damage due to excavation-induced ground movements. // Journal of Geotechnical and Geoenvironmental Engineering. 131, 2(2005), pp. 162-177. DOI: 10.1061/(ASCE)10900241(2005)131:2(162)

[16] Liu, Y.; Wang, X. D. Overview of the assessment on the damage from underground excavating on adjacent buildings. // Chinese Journal of Chemical Engineering. 5, 4(2008), pp. 841-847.

[17] Yu, G. M.; Yang, L. Estimation of damage degree of building and structures due to mining subsidence and the study of damage mechanism. // Journal of Fuxin Mining Institute. 11, 1(1992), pp. 41-45.

[18] China Coal Industry Bureau. Mining rules of left protective coal column for buildings, water, railway and main tunnel. China Coal Industry Publishing House, Beijing, 2000.

[19] Lian, C. J.; Liu, L. M. Fuzzy mathematical evaluation for masonry structure building's damage grade caused by coal mining. // Journal of Coal Science \& Engineering (China). 5, 1(1999), pp. 33-37.

[20] Guo, W. B.; Liu, Y. X.; Li, X. S. Fuzzy clustering analysis of mining induced damages of buildings. // Journal of Mining \& Safety Engineering. 24, 3(2007), pp. 288-292.

[21] Guo W. B.; Wu C. F. Deng K. Z. Artificial neural network prediction model of mining-induced damage of buildings. // Chinese Journal of Rock Mechanics and Engneering. 23, 4(2004), pp. 583-587.

[22] Liu, L. M.; Liu, H. L.; Lian, C. J. Matter-element model for building's damage grade evaluation and its application caused by mining subsidence. // Journal of China Coal Society. 29,1(2004), pp. 17-21.

[23] Harish, N.; Mandal, S.; Rao, S.; Patil, S.G. Particle swarm optimization based support vector machine for damage level prediction of non-reshaped berm breakwater. // Applied Soft Computing. 27, (2015), pp. 313-321. DOI: 10.1016/j.asoc.2014.10.041

[24] Kang, S.; Cho, S. Approximating support vector machine with artificial network for fast prediction. // Expert Systems with Applications. 41, 10(2014), pp. 4989-4995. DOl: 10.1016/j.eswa.2014.02.025

[25] Gao, J. B.; Gunn, S. R.; Harris, C. J. Mean field method for the support vector machine regression. // Neurocomputing. 50, (2003), pp. 391-405. DOI: 10.1016/S0925-2312(02)00573-8

[26] Li, Z. C.; Zhou, X. B.; Lin, Y. R.; Zou, X. Y. Prediction of protein structure class by coupling improved genetic algorithm and support vector machine. // Amino Acids. 35, 3(2008), pp. 581-590. DOI: 10.1007/s00726-008-0084-z

[27] Zhou, J.; Li, X. B.; Shi, X. Z. Long-term prediction model of rockburst in underground openings using heuristic algorithms and support vector machines. // Safety Science. 50, 4(2012), pp. 629-644. DOI: 10.1016/j.ssci.2011.08.065

[28] Cherkassky, V.; Ma, Y. Practical selection of SVM parameters and noise estimation for SVM regression. // Neural Networks. 17, 1(2004), pp. 113-126. DOI: 10.1016/S0893-6080(03)00169-2

[29] Wu, J. L.; Yang, S. X.; Liu, C. S. Parameter selection for support vector machines based on genetic algorithms to short-term power load forecasting. // Journal of Central South University (Science and Technology). 40, 1(2009), pp. 180-184.

[30] Boscardin, M. D. Building response to excavation-induced settlement. // Journal of Geotechnical Engineering Division, 
ASCE. 115, 1(1989), pp. 1-21. DOI: 10.1061/(ASCE)07339410(1989)115:1(1)

[31] Rankin, W. J. Ground movements resulting from urban tunneling: predictions and effects. // Conference of Engineering Geology of Underground Movements / Nottingham, 1988, pp. 79-92.

[32] Wang, J. Z.; Xing, A. S.; Wu, L. X. Protection and treatment of settlement induced by mining engineering. China Coal Industry Publishing House, Beijing, 1995.

[33] Chang, C. C.; Lin, C. J. LIBSVM: A library for support nector machines. // ACM Transactions on Intelligent Systems and Technology. 2, 3(2011), pp. 1-27. DOl: 10.1145/1961189.1961199

\section{Authors' addresses}

Lang Liu, Ph.D. (Corresponding author)

Energy School, Xi'an University of Science and Technology

NO. 58 Yanta Road, 740054 Xi'an, P. R. China

E-mail: csuliulang@163.com

\section{Xinping Lai, Ph.D., Professor}

Energy School, Xi'an University of Science and Technology

NO. 58 Yanta Road, 740054 Xi'an, P. R. China

E-mail: 1966478109@qq.com

\section{Ki-Il Song, Ph.D., Associate Professor}

Department of Civil Engineering, Inha University

100 Inha-ro, 402-751 Incheon, South Korea

E-mail: chosh@chonbuk.ac.kr

Dezheng Lao, Ph.D.

School of Civil \& Resource Engineering,

University of Western Australia

NO. 35 Stirling Highway, 6009 WA, Australia

E-mail: spring_xue@163.com 